3-1-2011

\title{
Social and emotional components of book reading between caregivers and their toddlers in a high-risk sample
}

Jennifer Riedl Cross

College of William and Mary, jrcross@wm.edu

Kathryn L. Fletcher

Kristie Speirs Neumeister

Follow this and additional works at: https://scholarworks.wm.edu/educationpubs

Part of the Gifted Education Commons

\section{Recommended Citation}

Cross, Jennifer Riedl; Fletcher, Kathryn L.; and Speirs Neumeister, Kristie, Social and emotional components of book reading between caregivers and their toddlers in a high-risk sample (2011). Journal of Early Childhood Literacy, 11(1), 25-46.

https://doi.org/10.1177/1468798410390894

This Article is brought to you for free and open access by the School of Education at W\&M ScholarWorks. It has been accepted for inclusion in School of Education Articles by an authorized administrator of W\&M ScholarWorks. For more information, please contact scholarworks@wm.edu. 


\section{Running Head: SOCIAL COMPONENTS OF BOOK READING}

Social and Emotional Components of Book Reading Between Caregivers and

Their Toddlers in a High Risk Sample

Jennifer Riedl Cross

01jrcross@bsu.edu

Kathryn L. Fletcher

klfletcher@bsu.edu

Kristie L. Speirs Neumeister

klspeirsneum@bsu.edu

Ball State University

Department of Educational Psychology TC 524

2000 W. University Avenue

Muncie, IN 47306

(765) $285-8500$

\section{Final version accepted for publication}

Cross, J. R., Fletcher, K. L., \& Speirs Neumeister, K. L. (2011). Social and emotional components of book reading between caregivers and their toddlers in a high-risk sample. Journal of Early Childhood Literacy, 11, 25-46. 


\begin{abstract}
In this collective case study of caregiver behaviors with their toddlers, two-minute videotaped reading interactions were analyzed using a constant comparative method. Twenty-four caregiver-toddler dyads from a high-risk sample of children prenatally exposed to cocaine were selected from a larger sample because they represented the extremes of expressive language scores on the Reynell Expressive Language Quotient at 36 months, 1 year after the reading interactions. Caregivers in the high-scoring group shared control of the book and discourse, were "in tune" with the child's needs and abilities, and answered their own questions to the children. This was in contrast to the behaviors of caregivers of the low-scoring children, who appeared unaware of the children's developmental needs in the interaction, particularly in their ability to respond to the questions posed. Implications of the results for future research on caregiver reading with young children are discussed.
\end{abstract}


Social and Emotional Components of Book Reading Between Caregivers and Their Toddlers in a High Risk Sample

Parent's reading to their children has been linked to increased language and literacy skills (Bus, van IJzendoorn, \& Pellegrini, 1995; Sénéchal \& LeFevre, 2002; Whitehurst \& Lonigan, 1998). Longitudinal research with preschoolers has also increased our understanding about how specific language and emergent literacy skills are enhanced with storybook reading (Sénéchal \& LeFevre, 2002; Storch \& Whitehurst, 2001;

Whitehurst \& Lonigan). Storybook reading has also been used as an intervention method to improve early language and literacy skills with preschool children at-risk for school failure (Zevenbergen \& Whitehurst, 2003) as well as children with language and/or communication disorders (van Kleeck \& Vander Woude, 2003).

Many parents report that they read to children before the age of three (Britto, Fuligni, \& Brooks-Gunn, 2002; Fletcher \& Reese, 2005; Raikes et al., 2006), but there has been less reading research devoted to reading to infants and toddlers than reading to preschoolers. Yet the frequency of reading to toddlers as well as starting to read to children at an earlier age have both been linked to language development (DeBaryshe, 1993; Fletcher \& Reese, 2005; Karrass \& Braungart-Reikert, 2005; Payne, Whitehurst, \& Angell, 1994). Despite the data on frequency of reading to young children, these studies did not examine caregiver behaviors during reading. Other researchers have investigated maternal reading behaviors with children under age 3 (Blake, MacDonald, Bayrami, Agosta, \& Milian, 2006; Deckner, Adamson, \& Bakeman, 2006; DeLoache \& DeMendoza, 1987; Fletcher, Cross, Tanney, Schneider \& Finch, 2008; Goodsitt, Raitan, \& Perlmutter, 1988; Karrass \& Braungart-Reikert, 2005; Martin, 1998; Murphy, 1978; 
Ninio \& Bruner, 1978; Sénéchal, Cornell, \& Broda, 1995; Snow \& Goldfield, 1982, 1983; Sulzby \& Teale, 1987; van Kleeck, Alexander, Vigil, \& Templeton, 1996;

Wheeler, 1983). Based on this research, the general trend emerges that parents reading with children under the age of 3 use a variety of reading behaviors that move from simple (attention-getting and labeling) to more advanced behaviors (comments, decontextualized language, questions) with their children's increasing age.

Although across studies there appears to be a general change in the types of utterances mothers use during reading, there is also substantial variability in mothers' reading behaviors (Britto, Brooks-Gunn, \& Griffin, 2006; Haden, Reese, \& Fivush, 1996; Scheffer Hammer, Nimmo, Cohen, Clemon Draheim, \& Achenbach Johnson, 2005; Hammett, van Kleeck, \& Huberty, 2003; Reese, Cox, Harte, \& McAnally, 2003). Several studies have revealed distinct maternal reading styles that were associated with children's language skills. Children of Story-Tellers (i.e., more talk, more decontextualized language and asked more questions) had higher expressive language scores compared to children of Story-Readers (i.e., less talk) in a low-income sample of adolescent mothers (Britto et al., 2006). In addition, the use of different reading styles may interact with children's language ability. In an experimental study that employed readers rather than mothers, 4-year-old children with higher language scores learned more vocabulary from readers with a Performance-oriented style (e.g., discussed story meaning at the end) compared to a Describer style (e.g., focus on labeling and describing pictures) whereas children with lower initial vocabulary learned more vocabulary with the Describer style (Reese \& Cox, 1999). Thus maternal reading styles may change over time with increases in developmental level (Deckner et al., 2006; Reese et al., 2003). 
The types of maternal reading behaviors and styles may be related to a more general relationship of attachment to their children. Recently, there has been increased attention devoted to how parenting and emotional factors may impact children's early literacy (Dickinson \& Neuman, 2006). Mothers used more responsive and engaging reading behaviors with securely attached children than mothers whose children had an insecure attachment status (Bus, Belsky, van IJzendoorn, \& Crnic, 1997; Bus \& van IJzendoorn, 1988, 1992). Previous researchers have demonstrated that securely attached children are more attentive, responsive, and evoke less discipline during book reading than insecurely attached children (Bus \& van IJzendoorn, 1988, 1997). Attachment security has been associated with maternal sensitivity (Ainsworth, Blehar, Waters \& Wall, 1978; de Wolff \& van IJzendoorn, 1997) and to higher-quality reading interactions in which the mother is more responsive to the child's interests and language level. Whereas children's attachment status provides a general indicator of the mother-child relationship quality, there have been no systematic attempts to analyze other social and emotional components during reading.

\section{Purpose of the Present Study}

The purpose of the present study was to examine the social and emotional climate during reading in a sample of toddlers with mild developmental delays. This study sought to explore what components of the reading interaction, in addition to maternal reading behaviors, might contribute to differences in children's language development. Previous research on this sample has revealed that caregiver's use of expansions and questions with their 24-month-old children during reading was related to children's 
expressive language at 30 months and children's attention at 24 months (Fletcher et al., 2008).

During the analysis of the videotaped data that led to this conclusion, it became apparent that there was more to the relationship between the caregivers and their toddlers beyond caregiver's reading behaviors. Systematic study was needed to investigate the qualities of this relationship. This study sought to identify the differences between the caregiver-child reading interactions of those children who scored highest on a 36-month expressive language scale and those who scored lowest. This analysis of 2-minute videotaped interactions goes beyond calculations of behavioral frequency to explore the context that may be contributing to later differences in children's language development.

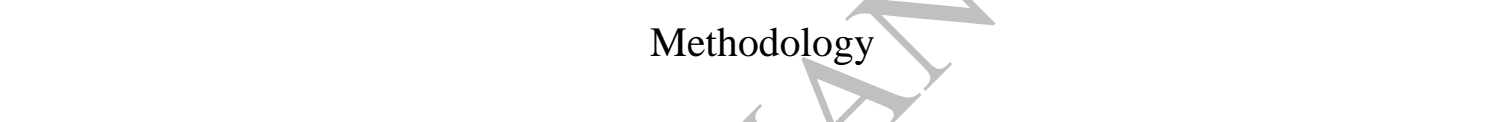

\section{Participants}

Participants were a subset of 24 caregiver-toddlers dyads selected from a larger sample of 87 24-month-old children enrolled in an early intervention program and their caregivers (Fletcher et al, 2008). The program provides intervention services to children and their families and referrals are based on prenatal exposure to cocaine (see Bono et al., 2005; Claussen et al., 2004 for more specific referral and inclusion criterion). The research component of this program received IRB approval and underwent yearly reviews. Caregivers for children enrolled in the program gave informed consent for all developmental assessments and protocols associated with this research. All children enrolled had mild to moderate delays, with enrollment criterion being a $25 \%$ developmental delay in one area of development on two measures mandated by the school district. 
The children selected for this study were chosen because they represented the extremes of expressive language scores 1 year after they were recorded in reading interactions with their primary caregivers. The reading interactions studied compose a clearly bounded system (Smith, 1978); the case is readily delimited (Merriam, 1998). Each case is intrinsically bound - the 2 minutes during which the caregiver was recorded reading to the child. The analysis is particularistic (focusing on the particular reading interaction), descriptive (resulting in a rich description of the caregiver and child behaviors during the interaction), and heuristic (exposing "previously unknown relationships...leading to a rethinking of the phenomenon" Stake, 1981, p. 47). In this collective case study, the cases were instrumental (Stake, 1998), selected to explore the differences between high and low expressive language scorers in these very narrow interactions.

Dyads were chosen based on children's scores on the Reynell Expressive Language Quotient at 36 months, 1 year after the recorded interactions. Reynell Developmental Language Scales (Reynell \& Gruber, 1990) is a standardized language assessment measuring verbal comprehension (nonverbal responses) and expressive language administered to children. From a list of the top and bottom 20 scorers on the Reynell Expressive Language Quotient, several dyads were eliminated due to technical problems or because the caregiver during the interaction was not their primary caregiver. The remaining interactions were analyzed until there was sufficient repetition in the results to conclude that saturation of the data had been reached; that is, new data fit into the existing categories without suggesting additional categories (Charmaz, 2000). The final sample for this study included 12 of the highest scorers and 12 of the lowest scorers 
on the Reynell Expressive Language Quotient (see Table 1). With 100 as the average score for the norming sample, very few of the high scoring participants in this at-risk sample even achieved an average score. Scores of the high scoring cases ranged from 89 to 113 , with a mean of 95 and mode of 89 . Low scoring cases ranged from 62 to 68 , with a mean of 64 and a mode of 63.

The majority of children (10 of the 12 high scorers and 11 of the 12 low scorers) received welfare or some other form of public assistance. Both high and low scorers were predominantly Black (high $n=9$, low $n=10$ ). Among the 12 high scorers, 2 were White and 1 was Hispanic. Two low scorers were Hispanic. For these two groups, there were no differences in reported frequency of reading in the home, $t(17)=-.596, p>.05$, or the amount of overall time that caregivers and their toddlers attended to the book during the 2-minute interaction, $t(14)=-.419, p>.05$.

\section{Procedure}

The experimenter gave caregivers a copy of Happy Days, a book with pictures of toddlers doing a variety of daily activities such as eating soup, or playing musical instruments. Caregivers were instructed to "Please look at this book as you would at home." Care was taken not to use the word "read" but instead to instruct caregivers to look at the book. Following these instructions, caregivers were left alone with the child for 2 minutes. Reading interactions were videotaped through a one-way mirror and transferred to DVDs for analysis. The interactions were viewed on a laptop computer with DVD-viewing software that allowed easy control (rewind, forward, etc.) of the 2minute interactions. 
Initial framework. Several of the interactions were observed to determine what elements of the interaction appeared to merit greater attention in the analysis. The guiding question of this research was "What differences exist in the reading interactions between high and low language scorers?" Based on prior research on caregiver reading behaviors and from observations of differences in the initial viewing of the interactions, four topics, description, physical behavior, speaking behavior, and reading behavior were placed on the framework for more detailed observations. A fifth topic, power relationships, was added as the interactions were being viewed. Questions about each of these topics were developed to assist in the analysis of the observations. Not all questions were relevant to all interactions.

Added categories. Using this framework, the researcher watched the interactions as many times as needed to answer the questions, keeping notes about what was observed. These notes were comparable to field notes used in participant observations. As the interactions were viewed repeatedly (a constant comparative method [Glaser, 1992] with video), several of the caregivers' behaviors stood out and were coded. Three more categories emerged during the viewings as important to the interaction: high expansions (the caregiver used elaborate or frequent expansions), in tune (the caregiver appeared to understand and respond to the child's needs), and answer (the caregiver answered his/her own questions to the child). As a category was added, all interactions were reviewed to code the caregiver's behavior in the new category. These categories will be described in depth in the Findings section.

Category coding. Category coding was a compressed version of the responses to framework questions collected in the field notes. For example, for the category reading 
behavior, question responses might look similar to these notes about the reading

interaction with Steve ${ }^{1}$ :

Reading behavior

1. She reads every page. Even the author's name. Points as she reads words.

2. Low $\%$ is reading because she's describing so much, but she reads every page.

3. Lots of description "And then he has a hammer. And it says Fix-it Day. OK.

So he's trying to fix something here. I don't know what it is."

The coded category, however, is simply "yes," indicating that reading did, in fact, occur

for Steve. The more in-depth question responses were helpful in the creation of additional categories, such as the Answer category.

The final section of the field notes was a general description. This included a chronology of actions with specific examples of caregiver and child behavior along with the researcher's impressions. The following excerpt is from the general description of Teresa's interaction:

"Child is in lap, Mom holding book in front of both of them. "Toy. Turn the page. Turn the page...." She tries to help child do it. "Turn this way." Then child tries to grab the whole book. ... "Book, see book? Point to the book. Show me the book." Child hits the page. Mom laughs. "See car?" Child hits book again. "Stop doing that. Say car."

Validation. Unlike with participant observations, verification of the researcher's analysis with the participants was not possible with this sample. In a form of investigator triangulation (Janesick, 1998), a second researcher observed a sample of the interactions to evaluate the appropriateness of the framework. The two researchers discussed their interpretations and reached consensus on the interactions both observed. This is a common methodology used in qualitative research. Guba and Lincoln (1994) suggest that the purpose of constructivist inquiry such as this aims "toward consensus but [is] still

${ }^{1}$ All subject names are pseudonyms. 
open to new interpretations as information and sophistication improve" (p. 113). This method of triangulation was deemed most appropriate for this novel research method.

\section{Findings}

Similarities Between Dyads Whose Children Scored High or Low on Language at 36 Months

Description. For several of the categories coded for each of the participants, there were no or only negligible differences. Both high and low scoring dyads were ethnically similar, although the only 2 White participants in the sample were in the high scoring group. The only two male caregivers in the sample were also in the high scoring group. The two groups did not differ in the numbers receiving public assistance (see Table 1 for sample demographics).

Physical closeness. In developing the framework for observations, it became clear that some toddlers remained in close physical proximity to their caregiver (CG), whereas others did not. Closeness was coded "yes" if the dyads were in close physical contact with each other for the majority of the time during the interaction. This often meant the child sat in the caregiver's lap. For example, the following descriptions in the field notes were coded positively for physical closeness:

Child in CG's lap, resting against crook of his arm. CG holds book in front of them. (Michelle)

CG [child] sits in her lap, her arms around him, holding book in front of both of them. (Clifton)

CG is holding him in her lap with arms around him as they read. (Jerome) Both sit on floor. CG with legs spread wide and him between them, book on his satchel in front of them. (Steve)

The following descriptions were coded negatively for physical closeness: 
CG sits with legs stretched out, holding book in front of her as if reading to herself. Child sits beside her sideways, leaning in, but not touching. (Sheree) CG sitting cross-legged, facing child. Child has feet on CG's feet. (Natalie) At first he [child] is in her lap, holding book, but very soon he crawls out from her hold. He pushes against her after about 30 seconds. (James)

CG sits in chair holding book upside down towards child, child faces her standing. (Althea)

In some of the interactions, there was some physical closeness, but not for the majority of the time. These were coded "some." There did not appear to be any major differences in physical contact between high and low scoring dyads, with about half of each group being physically close and about half not being close.

Reading behaviors. There were no differences between the groups in whether or not caregivers read the book during the interaction. Caregivers read to some of the children in both high and low scoring groups. Among high scorers, 4 caregivers did not read at all or only read one time in the 2-minute interaction. Among low scorers, 6 caregivers did not engage in reading or did so only once.

Speaking behaviors. Both high and low scoring participants were exposed to clear enunciation and poor enunciation (e.g., [Andre] "Poor enunciation. 'What is right dere?'"). This did not appear to be an area in which the groups differed.

Differences Between Dyads Whose Children Scored High or Low on Language at 36 Months

Description. Although the high and low scoring children were similar on most demographic variables, there was a noticeable difference in gender. There were 7 females in the high scoring group, but only 3 in the low scoring group. Previous researchers have demonstrated that females consistently outperform males on language measures across early childhood (Bornstein, Hahn, \& Haynes, 2004). 
High expansion. In collecting examples and impressions of reading behaviors, it became clear that some caregivers expanded on the pictures or text in Happy Days more often or differently than others. Expansions involved using additional vocabulary and descriptors of the pictures beyond reading the text or simple labeling (e.g., It's a bowl of hot soup. It is tomato soup. She is eating that tomato soup). Upon closer examination, these high level expansions appeared to differ between the two groups. Bethany's caregiver encourages her to explore the different elements of the picture: "Look at the little boy. He eating his donuts. Look at the teddy bear. And the table... Look at the little boy. He smiling? Heee heeee (smiling gesture)."

Half of the high scoring toddlers were offered a more elaborate description of what is happening in the picture book than their low scoring peers. In an example of a high quality expansion, Steve's caregiver said, "See what she's got on? She got on a hat and some beads and everything. Now see this is a rocking horse...[Gestures rocking horse and later piano].” In the same interaction, Steve's caregiver also used the words "then" and "now" often, describing a progression of time in the story. Some caregivers were not elaborate in their expansions, but had a high frequency of expansions as is evident in this observation note from James's interaction: "Where's the hammer? Fix it." "You want to turn the page?" "What's this? Bubbles? Blow a bubble." and they do. "And what's this? Building a castle." Caregivers of low scoring toddlers, on the other hand, were more likely to give labels or ask questions about the picture than give expansions.

Caregivers of two of the low scoring children were coded as having high level expansions, but in both cases, the child was noticeably unreceptive to the caregivers' efforts. Ramone's caregiver carried out all the same behaviors as the caregivers in the 
high scoring group (e.g., 'Lots of positive sounds, questions. 'Can you pop it?' on the bubble page. 'Blow' and he did. 'Do you blow bubbles with Miss Jennifer?' 'Look at that!'”), but Ramone refused to engage in reading with her. He constantly ran around the room, returning at the caregiver's request, but only momentarily.

Answering questions. Caregivers with children in the high scoring group also answered their own questions more than the caregivers in the low scoring group. All but one of the caregivers in the high scoring group did this, but only 3 of the caregiyers in the low scoring group did so. Caregivers of high scorers asked frequent questions, but they did not necessarily wait for the child to respond. Bethany's caregiver asks, "What's she doing? She eating her food, right?" Maria's caregiver asks, "What that say?" "It say good morning day." Lamont is asked, "What's she doing? She eating?" and James is asked, "What's this? Shovel? What's the baby doing? He's getting dressed." Eleven out of 12 caregivers of high scoring toddlers answered their own questions.

Although caregivers of low scorers also asked frequent questions, 9 out of the 12 did not follow the question with an answer. For example, Jerome's caregiver asks many questions after reading the text: "Warm soup day." "Donut day." "Who is this?" "Tea party day. What is this? Who is that?" Andre's caregiver encourages him to "look, look, look. Music day. Look. What that? Look. Music Day." Eduardo's caregiver asks, "Where the choo choo? Oh! What's that?" Although these caregivers asked the child a question, they did not give the child an indication of the desired response. Caregivers of low scoring children often asked a question repeatedly with no response from the child, or they moved on without ever answering the question asked. 
In tune. This category of behaviors - in tune - emerged late in the analysis after observing the unusual behaviors of Eduardo's caregiver. The caregiver appeared to have very little understanding of his needs or abilities. The data illustrate this when he attempted to give her the book by dropping it near her. She simply picked it up and handed it back, never considering that he wanted her to have it.

In the high scoring group, most caregivers seemed to be good judges of their child's needs and abilities, as in the case of Natalie: "Child gets very excited, claps her hands and says "Horsie". The caregiver immediately recognizes the child's interest: "Where the horsie at? Show me the horsie" child points, "Alright!" Bethany's caregiver patiently showed her child the mechanics of reading a book, teaching her how to turn just one page; "Turn the page. Turn one, Deedee. See, one."

Among the high scorers, 2 of the 12 caregivers were not in tune with their child's needs. Terrell's caregiver could not stop laughing long enough to read to her child, and she was physically forceful with him as she hugged and kissed him, pushing him to the ground as she leaned into her reading. Maria's caregiver, one of only 2 male caregivers, pointed to a phrase in the book and asked "What that say?" a question far beyond the ability level of a 24 -month-old.

In the low scoring group, there were numerous examples of caregiver's failure to interpret the wishes and ability level of their child. As in other low scoring cases, Eduardo's caregiver repeatedly asked questions that were impossible for the child to answer. She asks him 9 times to tell her "What's she have on her head?" It should have been evident that he could not (or would not) respond after 2 or 3 times. She was not in tune with her child's needs. 
Upon examination, it became clear that many of these caregivers were similarly unaware of what their child was attempting to do or able to do. The frequent "What's that?" questions are an example of this. When a caregiver repeatedly asks questions that the child cannot answer, a different strategy is in order, perhaps along the lines of the answering strategy the high scorer's caregivers used. Only 3 of the low scoring caregivers appeared to be in tune with their child, with a $4^{\text {th }}$ caregiver somewhat in tune. The remaining 8 caregivers made mistakes in interpreting their child's needs. Takira's caregiver, for example, attempted to spell out the words "Good Morning," pointing to each letter, as the child rapidly lost interest in this activity. In another example, Teresa's caregiver appeared to have no understanding of her child's behavior:

"Book, see book? Point to the book. Show me the book." Child hits the page. Mom laughs. "See car?" Child hits book again. "Stop doing that. Say car." Smacks child's hand.... Child walks away, making happy noises. Mom laughs, encouraging her. "Rocking horse. Puppy." Then [caregiver begins singing] "Say shake, shake, shake. Shake the devil off. See?" while child is walking around the room. Mom tells her to sit in the chair, but she comes back to sit by mom, just as she (mom) is taking off her shoes. Child sits down, picking up book, but Mom thinks she is going to take off her shoes. "No, don't you take off your shoes. NO! Don't take them off." when it is clear that child wanted the book. Child picks up book and mom says "Read the book." And turns it around the right way for her to look at.

Power relationships. Early in the analysis, it became apparent that the dyads differed in who controlled the greater share of power during reading. The questions used 
in the framework were: 1) Who is dominant? How can you tell? 2) What behaviors show it? and 3) Is it constant? Power had multiple dimensions. It might have been evident in who controlled the book, in who dominated the discourse, or in which member paid attention to the other. All of the caregivers of high scoring toddlers shared power with their children, whereas in only 2 cases did caregivers in the low scoring group share power with their children. In the 10 remaining dyads in the low scoring group, power was in the hands of either the child or the caregiver, often quite literally in the form of the book.

Among the high scoring dyads, the caregiver willingly shares control of the book. Some of the caregivers in the high scoring group offer the child the book (e.g., James) or let the child have it when they reach for it (e.g., Terrell). Power sharing was evident when Michelle's caregiver let her turn the pages and take control of the book as soon as she showed an interest in it. Bethany shared power with her caregiver, who held the book, but let Bethany turn the pages. Steve's caregiver waited for him to finish studying the book before taking it to begin reading.

The book was frequently the focus of a power struggle among the low scoring dyads. For example, in this note about Teresa, the power dynamic was evident: "Mom definitely has the power. Child wants it, but mom doesn't relinquish. She lets child take book, but commands her to turn pages and let her see." Even though the child held the book, the caregiver controlled the turning of pages through her commands. The same experience occurred when Clifton began trying to turn the page and his caregiver moved the book out of his reach, saying "OK. Wait, wait." She turned the page herself and they 
continued. Takira had full control of the book in their interaction, but this was primarily due to a lack of engagement from her caregiver.

Power was exerted not only in control over the book but also involved controlling behavior in other aspects of the interaction. For instance, Sheree remained passive throughout the interaction, with her caregiver completely in charge of all comments or actions: "Oh, look at the bear... She fixing tea for the bear. See the tea? You want tea? See the bear? You want tea?" Although Sheree attended to the book, she did not involve herself in reading with her caregiver, who controlled the book and the speech in the interaction.

Power was also demonstrated during reading in attention to the other member or turn-taking in either speech or reading behavior. Caregivers in the high scoring cases responded to the child's redirections, often made by pointing. For example, James's caregiver said, "What's this? Building a castle." The child said "du" and she responded “A duck? It's a duck. You're right!” In attending to his interest, the caregiver respected his preference for the duck over the castle-building. Such willing transfer of the caregiver's attention to the child's did not occur among the low scoring dyads.

Ramone controlled his reading interaction by attending to the caregiver's requests briefly and infrequently. As he ran around the room, the caregiver made every effort to engage him with the book, but any success was short lived. Eduardo also had the power in his interaction, but it was clear that the caregiver gave him the power, rather than the child wresting it from her. At one point, "he closes the book and drops it in her direction. She picks it up and returns it to him. I think he would let her have it, but she wants him to 
have it. When she asks several times for a hug, he doesn't respond." Eduardo was in full control of the interaction.

\section{Discussion}

The purpose of the present study was to examine the social and emotional climate during reading in a sample of toddlers with mild developmental delays. The sample was relatively homogeneous with respect to ethnicity and sex of caregiver so it was not surprising that these descriptors did not differ in the two groups. One descriptor that did relate to language scores was the child's sex. There were more females in the high scoring language group than males. Previous researchers have demonstrated that females consistently outperform males on language measures across early childhood (Bornstein, Hahn, \& Haynes, 2004).

There were also some observed differences between the two groups in caregiver's reading behaviors that can be associated with the social/emotional nature of the reading interaction. Differences in caregiver's use of expansions, answering their own questions and being "in tune" with their children represent different components related to caregiver's sensitivity and responsiveness to their children. Using a Vygotskian theoretical approach, caregivers who are more sensitive to their children's language abilities can structure their behaviors within their child's zone of proximal development (Fletcher \& Reese, 2005; Miller \& Davis, 1992). It is likely that positive reading interactions involve adult's use of reading strategies that encourage children's participation at their developmental level. In the current study, caregivers in the high scoring group's using expansions, answering their questions and being in tune with their 
children indicate that they may have considered their children's stage of language development during reading more so than caregivers in the low scoring group.

The fact that caregivers in the high scoring language group used expansions may indicate that they were sensitive to their children's vocabulary development. Expansions increased the amount of verbal input during reading for children. Caregivers in the high language scoring group used expansions more than caregivers in the low scoring group. In previous research, caregiver's use of expansions was associated with children's subsequent language scores 6 months later and children's concurrent attention measures (Fletcher et al., 2008). Reading styles that are characterized by increased amount of talk and description have been related to children's language scores (Britto et al., 2006), particularly those children with less advanced language skills (Reese \& Cox, 1999).

Caregiver's strategy of answering their own questions represents another example of caregiver sensitivity. In some ways, this strategy was both an expansion (i.e., extended verbal input) and a way to engage their children during reading. All children had relatively low language scores even 1 year later and thus, for all children, their language was likely extremely limited at 24 months. As such, caregivers in the high language group seemed more sensitive to the fact that children were not going to respond to their questions and they provided the answer for them. In a sense, these caregivers also modeled that reading can be a time of conversation about pictures and stories. Other research has shown that parents may differ in their beliefs about the function of reading to children, ranging from entertainment to teaching literacy (Meagher, Arnold, Doctoroff, \& Baker, 2008). In contrast, caregivers in the low language scoring group displayed limited sensitivity to their children's developmental abilities by repeatedly asking them 
the same question. Again, for this sample at age two, it was unlikely that children in either group were going to respond to caregiver's questions. To our knowledge, there is no previous research that has described this behavior during reading.

Answering questions is also associated with being "in tune." Caregivers in the high language group appeared better able to gear the reading interaction to their children's abilities with the use of developmentally appropriate behaviors and expectations. Examples such as spelling words and asking toddlers to read words indicate a limited understanding of their children's developmenta/level. In these interactions, toddlers quickly lost interest. Caregivers in the low scoring group also misunderstood their children's attempts to give them and/or pick up the book. Caregivers responded to these attempts with either indifference or harsh words. These caregivers seemed to have limited sensitivity about their children's language abilities and what reading behaviors might be developmentally appropriate to engage their children during reading. Such sensitivity may be important in order for caregivers to more closely "match" their behaviors to their children's linguistic development (Fletcher \& Reese, 2005; Hammett et a1., 2003; Hunt \& Paraskevopoulos, 1980; Reese et al., 2003).

Rowe (2008) found a relationship between such "in tune" behaviors and the SES of her sample, with high SES subjects possessing greater knowledge about child development and behaving in greater accord with recommendations of child development experts than subjects of low SES. In this study, public assistance did not differ between the high and low scoring groups, indicating that income level may not be the significant aspect of SES related to a parent's awareness of the child's development. Caregiver's education level, which was not available in this study, may play a more significant role. 
Perhaps the most interesting findings of this study were the power sharing and power struggles that differed across the two groups. Caregivers in the high scoring group seemed to share the book with their children in the form of letting them hold the book, turn pages, and physically touch the book more so than the caregivers in the low scoring group. Attempts to physically interact with the book were often met with discipline by caregivers in the low scoring group. On the other hand, caregivers in the high scoring group readily let children hold the book, turn pages, and more generally share in the control of the book during reading. These caregivers were also more likely to follow the child's interest during reading and not try to redirect their attention.

These power dynamics have important implications for both language development and children's motivation. Caregiver's controlling behavior is likely to reduce children's intrinsic motivation for reading with caregivers. This was demonstrated by the fact that toddlers quickly lost interest when caregivers took control during reading. These findings overlap with research with older children regarding the positive impact of parental support of autonomy on children's achievement motivations (Deci \& Ryan, 1985; Grolnick, 2002; Koestner, Ryan, Bernieri, \& Holt, 1984).

In regard to language development, book sharing may also affect language learning during the reading interaction. Following the child's lead is also a component of dialogic reading, a technique used by parents and teachers that has been associated with increased language scores (see Morgan \& Meier, 2008; Whitehurst \& Lonigan, 1998). Therefore, parental reading strategies aimed at sharing the reading interaction with young children may impact language development. This may be particularly true for males, who made up the majority of the low scoring group in this study. Parental support of their 
son's, but not daughter's, autonomy was found to be related to later reading achievement (National Institute of Child Health and Human Development, 2008). Perhaps there is an effect of gender on parent-child interactions that manifests in power sharing differences for young boys and girls.

In summary, it is likely that these relationships provide preliminary data that suggest the complexity of book reading with young children. Affective factors such as caregiver's sensitivity, responsiveness, and autonomy support during reading relate to cognitive aspects of reading such as joint attention and caregiver's reading strategies. And in turn, these relationships likely interact to produce differential children's outcomes related to language and motivation for reading. For example, caregiver's ability to establish joint attention may be affected by the emotional nature of the relationship. Disorganized attachment status in infants prenatally exposed to cocaine was found at elevated rates and related to low rates of children's initiating joint attention with an experimenter (Claussen et al., 2004). Dyads with insecure attachment status often displayed overcontrolling behaviors with their children during reading, likely reducing children's attention and motivation (Bus et al., 1997). The results of the current study as well as this previous research indicate that more investigation is necessary to understand these complex interactions.

\section{Limitations}

The findings of this study suggest that future research into the social and emotional components of book reading with young children should include information concerning parental knowledge about child development and attitudes about reading to children. Attachment status, which was unavailable for these subjects, may also be 
predictive of the parents' power sharing and awareness of the child's needs, which appear to be related to language development in this sample. Future research should explore these components in a broader sample.

\section{Conclusion}

In this sample, it appears that the social and emotional components of reading to young children at high risk for academic failure are related to later language development. The caregivers of the most successful children in this study, as measured by their Reynell Expressive Language Quotient at 36 months, engaged the children with greater responsiveness to their needs, supportive of their autonomy and willing to “acquiesce to children's requests" (Baumrind, 2005, p. 61). These more responsive parents also aided their children's language development by answering the questions they posed during the reading. Such a strategy could easily be taught to parents of high-risk children, with the potential for multiple positive outcomes. Parents may develop an improved recognition of their child's developmental needs as they learn the child is not ready to respond to their questions. Additionally, the child will be exposed to more words to describe her or his environment, a deficit found among low SES families (Hart \& Risley, 2003). More positive early reading interactions are likely to enhance language and literacy skills (Bus et al., 1995; Sénéchal \& LeFevre, 2002; Whitehurst \& Lonigan, 1998). 


\section{References}

Ainsworth, M. D. S., Blehar, M. C., Waters, E., \& Wall, S. (1978). Patterns of attachment: A psychological study of the strange situation. Hillsdale, NJ: Erlbaum.

Baumrind, D. (2005). Patterns of parental authority and adolescent autonomy. New Directions for Child and Adolescent Development, 108, 61-69.

Blake, J., Macdonald, S., Bayrami, L., Agosta, V., \& Milian, A. (2006). Bøok reading styles in dual-parent and single mother families. British Journal of Educational Psychology, 76(3), 501-515.

Bono, K. E., Dinehart, L. H., Claussen, A. H., Scott, K. G., Mundy, P. C., \& Katz, L. F. (2005). Early intervention with children prenatally exposed to cocaine:

Expansion with multiple cohorts. Journal of Early Intervention, 27(4), 268-284.

Bornstein, M. H., Hahn, C-S., \& Haynes, O. M. (2004). Specific and general language performance across early childhood: Stability and gender considerations. First Language, 24(72), 267-304.

Britto, P. R., Brooks-Gunn, J., \& Griffin, T. M. (2006). Maternal reading and teaching patterns: Associations with school readiness in low-income African American families. Reading Research Quarterly, 41(1), 68-89.

Britto, P.R., Fuligni, A.S., \& Brooks-Gunn, J. (2002). Reading, rhymes, and routines: American parents and their young children. In N. Halfon, K. T. McLearn, \& M. A. Schuster, (Eds.), Child rearing in America: Challenges facing parents with young children (pp. 117-145). Cambridge, UK: Cambridge University Press. 
Bus, A. G., Belsky, J., van IJzendoorn, M. H., \& Crnic, K. (1997). Attachment and bookreading patterns: A study of mothers, fathers, and their toddlers. Early Childhood Research Quarterly, 12, 81-98.

Bus, A. G. \& van IJzendoorn, M. H. (1988). Mother-child interactions, attachment, and emergent literacy: A cross-sectional study. Child Development, 59, 1262-1272.

Bus, A. G. \& van IJzendoorn, M. H. (1992). Patterns of attachment in frequently and infrequently reading mother-child dyads. Journal of Genetic Psychology, 153, $395-403$.

Bus, A. G. \& van IJzendoorn, M. H. (1997). Affective dimension of mother-infant picture book reading. Journal of School Psychology, 35, 47-60.

Bus, A. G., van IJzendoorn, M. H., \& Pellegrini, A. D. (1995). Joint book reading makes for success in learning to read: A meta-analysis on intergenerational transmission of literacy. Review of Educational Research, 65, 1-21.

Charmaz, K. (2000). Grounded theory: Objectivist and constructivist methods. In N. K. Denzin \& Y. S. Lincoln (Eds.), Handbook of qualitative research $\left(2^{\text {nd }}\right.$ ed., pp. 509-535). Thousand Oaks, CA: Sage.

Claussen, A. H., Scott, K. G., Mundy, P. C., \& Katz, L. F. (2004). Effects of three levels of early intervention services on children prenatally exposed to cocaine. Journal of Early Intervention, 26(3), 204-220.

DeBaryshe, B. D. (1993). Joint picture book reading correlates of early oral language skill. Journal of Child Language, 20, 455-461.

Deckner, D. F., Adamson, L. B., \& Bakeman, R. (2006). Child and maternal contributions to shared reading: Effects on language and literacy development. 
Journal of Applied Developmental Psychology, 27(1), 31-41.

Deci, E., \& Ryan, R. (1985). Intrinsic motivation and self-determination in human behavior. New York: Plenum.

DeLoache, J. S. \& DeMendoza, O. A. P. (1987). Joint picturebook interactions of mothers and 1-year-old children. British Journal of Developmental Psychology, 5, 111-123.

de Wolff, M. S., \& van IJzendoorn, M.H. (1997). Sensitivity and attachment: A metaanalysis on parental antecedents of infant attachment. Child Development, 68, 571-591.

Dickinson, D. K., \& Neuman, S. (2006). Handbook of early literacy research (2 $2^{\text {nd }}$ ed.). New York: Guilford Press.

Fletcher, K. L., Cross, J. R., Tanney, A. L., Schneider, M., \& Finch, W. H. (2008). Predicting language development in children at risk: The effects of quality and frequency of caregiver reading. Early Education and Development: Parent-Child Interaction and Early Literacy Development, 19(1), 89-111.

Fletcher, K. L. \& Reese, E. (2005). Picture book reading with young children: A conceptual framework. Developmental Review, 25, 64-103.

Glaser, B. G. (1992). Basics of grounded theory analysis: Emergence vs. forcing. Mill Valley, CA: Sociology Press.

Goodsitt, J., Raitan, J.G., \& Perlmutter, M. (1988). Interaction between mothers and preschool children when reading a novel and familiar book. International Journal of Behavioral Development, 11, 489-505. 
Grolnick, W. S. (2002). Review of the psychology of parental control: How well-meant parenting backfires. Adolescence, 37(148), 858-859. ??

Guba, E. G., \& Lincoln, Y. S. (1994). Competing paradigms in qualitative research. In N. K. Denzin \& Y. S. Lincoln (Eds.) Handbook of qualitative research (pp. 105117). Thousand Oaks, CA: Sage.

Haden, C. A., Reese, E., \& Fivush, R. (1996). Mothers' extratextual comments during storybook reading: Stylistic differences over time and across texts. Discourse Processes, 21, 135-169.

Hammett, L. A., van Kleeck, J., \& Huberty, C. J. (2003). Patterns of parents' extratextual interactions during book sharing with preshool children: A cluster analysis study. Reading Research Quarterly, 38(4), 442-468.

Hart, B., \& Risley, T. R. (2003). The early catastrophe. Education Review, 17(1), 110118.

Hunt, J. M., \& Paraskevopoulos, J. (1980). Children's psychological development as a function of the inaccuracy of their mothers' knowledge of their abilities. Journal of Genetic Psychology, 136(2), 285-298.

Janesick, V. J.(1998). The dance of qualitative research design: Metaphor, methodology, and meaning. In N. K. Denzin \& Y. S. Lincoln (Eds.), Strategies of qualitative inquiry (pp. 35-55). Thousand Oaks, CA: Sage.

Karrass, J., \& Braungart-Reikert, J. M. (2005). Effects of shared parent-infant book reading on early language acquisition. Developmental Psychology, 26(2), 133148. 
Koestner, R., Ryan, R. M., Bernieri, F., \& Holt, K. (1984). Setting limits on children's behavior: The differential effects of controlling vs. informational styles on intrinsic motivation and creativity. Journal of Personality, 52(3), 233-248.

Martin, L. E. (1998). Early book reading: How mothers deviate from printed text for young children. Reading Research and Instruction, 37, 137-160.

Meagher, S. M., Arnold, D. H., Doctoroff, G. L., \& Baker, C. N. (2008). The relationship between maternal beliefs and behavior during shared reasoning. Early Education and Development, 19(1), 138-160.

Merriam, S. B. (1998). Qualitative research and case study applications in education. San Francisco: Jossey-Bass.

Miller, S. A., \& Davis, T. L. (1992). Beliefs about children: A comparative study of mothers, teachers, peers, and self. Child Development, 63, 1251-1265.

Morgan, P. L., \& Meier, C. R. (2008). Dialogic reading's potential to improve children's emergent literacy skills and behavior. Preventing School Failure, 52(4), 11-16.

Murphy, C. M. (1978). Pointing in the context of a shared activity. Child Development, $49,371-380$

National Institute of Child Health and Human Development Early Child Care Research Network. (2008). Mothers' and fathers' support for child autonomy and early school achievement. Developmental Psychology, 44(4), 895-907.

Ninio, A. \& Bruner, J. (1978). The achievement and antecedents of labelling. Journal of Child Language, 5, 1-15. 
Payne, A. C., Whitehurst, G. J., \& Angell, A. L. (1994). The role of home literacy environment in the development of language ability in preschool children from low-income families. Early Childhood Research Quarterly, 9, 427-440.

Raikes, H., Pan, B.A, Luze, G., Tamis-LeMonda, C.S., Brooks-Gunn, J., Constantine, J., Tarullo, L. B., Raikes, H. A., \& Rodriguez, E. T. (2006). Mother-child bookreading in low-income families: Correlates and outcomes during the first three years of life. Child Development, 77, 924-953.

Reese, E., \& Cox, A. (1999). Quality of adult book reading affects children's emergent literacy. Developmental Psychology, 35, 20-28.

Reese, E., Cox, A., Harte, D., \& McAnally, H. (2003). Diversity in adults'styles of reading books to children. In A. van Kleeck, S. A. Stahl, \& E. B. Bauer (Eds.), On reading books to children: Parents and teachers (pp. 37-57). Mahwah, NJ:

Erlbaum.

Reynell, J. K., Gruber, C. P. (1990). Reynell developmental language scales. Los Angeles: Western Psychological Services.

Rowe, M. L. (2008). Child-directed speech: Relation to socioeconomic status, knowledge of child development and child vocabulary skill. Journal of Child Language, 35, $185-205$.

Scheffer Hammer, C., Nimmo, D., Cohen, R., Clemon Draheim, H., \& Achenbach Johnson, A. (2005). Book reading interactions between African American and Puerto Rican Head Start children and their mothers. Journal of Early Childhood Literacy, 5(3), 195-228. 
Sẻnẻchal, M., Cornell, E.H., \& Broda, L.S. (1995). Age-related differences in the organization of parent-infant interactions during picture book reading. Early Childhood Research Quarterly, 10, 317-337.

Sẻnẻchal, M. \& LeFevre, J.A. (2002). Parental involvement in the development of children's reading skill: A five-year longitudinal study. Child Development,73, 445-460.

Smith, L. M. (1978). An evolving logic of participant observation, educational ethnography and other case studies. In L. S. Shulman (Ed.), Review of research in education (Vol. 6, pp. 316-377). Itasca, IL: Peacock

Snow, C.E. \& Goldfield, B.A. (1982). Building stories: The emergence of information structure from conversation and narrative. In D. Tannen (Ed.), Analyzing discourse: Text and talk. Washington, DC: Georgetown University Press.

Snow, C.E. \& Goldfield, B.A. (1983). Turn the page please: Situation-specific language acquisition. Journal of Child Language, 10, 551-569.

Stake, R. E. (1981). Case study methodology: An epistemological advocacy. In W. W. Welsh (Ed.), Case study methodology in educational evaluation. Minneapolis, MN: Minnesota Research and Evaluation Center.

Stake, R. E. (1998). Case studies. In N. K. Denzin \& Y. S. Lincoln (Eds.), Strategies of qualitative inquiry (pp. 86-109). Thousand Oaks, CA: Sage.

Storch, S. A. \& Whitehurst, G. J. (2001). The role of family and home in the developmental course of literacy in children from low-income backgrounds. In P. R. Britto \& J. Brooks-Gunn, (Eds), New Directions in Child Development: The 
role of family literacy environments in promoting young children's emerging literacy skills (pp. 53-71). San Francisco: Jossey-Bass/Pfeiffer.

Sulzby, E. \& Teale, W. H. (1987). Young children's storybook reading: Longitudinal study of parent-child interaction and children's independent functioning (Final report to the Spencer Foundation). Ann Arbor, Michigan. (ERIC Document Reproduction Service No. ED 334541)

van Kleeck, A., Alexander, E.I., Vigil, A., Templeton, K.E. (1996). Verbally modeling thinking for infants: Middle-class mothers' presentation of information structures during book sharing. Journal of Research in Childhood Education, 10, 101-113. van Kleeck, A., \& Vander Woude, J. (2003). Book sharing with preschoolers with language delays. In A. van Kleeck, S. A. Stahl, \& E. B. Bauer (Eds.), On reading books to children: Parents and teachers (pp. 58-92). Mahwah, NJ: Erlbaum.

Wheeler, M.P. (1983). Context-related age changes in mothers' speech: Joint book reading. Journal of Child Language, 10, 259-263.

Whitehurst, G. J., \& Lonigan, C. J. (1998). Child development and emergent literacy. Child Development, 68, 848-872.

Zevenbergen, A. A. \& Whitehurst, G. J. (2003). Dialogic reading: A shared picture book reading intervention for preschoolers. In A. van Kleeck, S. A. Stahl, \& E. B.

Bauer (Eds.), On reading books to children: Parents and teachers (pp. 177-200). Mahwah, NJ: Lawrence Erlbaum. 
Table 1.

Table 1. Participant Demographics

\begin{tabular}{|c|c|c|c|c|c|c|}
\hline Name* & $\begin{array}{c}\text { Reynell } \\
\text { Expressive } \\
\text { Score at } 36 \\
\text { months }\end{array}$ & $\begin{array}{c}\text { Caregiver } \\
\text { Gender }\end{array}$ & $\begin{array}{c}\text { Child } \\
\text { Gender }\end{array}$ & $\begin{array}{c}\text { Child } \\
\text { Ethnicity }\end{array}$ & $\begin{array}{l}\text { Received } \\
\text { Welfare }\end{array}$ & $\begin{array}{c}\text { Received } \\
\text { Public } \\
\text { Assistance }\end{array}$ \\
\hline Althea & 113 & $\mathrm{~F}$ & $\mathrm{~F}$ & $\mathrm{~B}$ & $\mathrm{Y}$ & $\mathrm{Y}$ \\
\hline Bethany & 106 & $\mathrm{~F}$ & $\mathrm{~F}$ & $\mathrm{~B}$ & $\mathrm{Y}$ & $Y Y$ \\
\hline Antoine & 103 & $\mathrm{~F}$ & $\mathrm{M}$ & B & $\mathrm{P}$ & $Y$ \\
\hline Chantelle & 96 & $\mathrm{~F}$ & $\mathrm{~F}$ & $\mathrm{~B}$ & $Y$ & $\mathrm{Y}$ \\
\hline James & 96 & $\mathrm{~F}$ & $\mathrm{M}$ & $\mathrm{W}$ & $\mathrm{N}$ & $\mathrm{N}$ \\
\hline Lamont & 94 & $\mathrm{~F}$ & $\mathrm{M}$ & $\mathrm{B}$ & $\mathrm{N}$ & $\mathrm{N}$ \\
\hline Deborah & 94 & $\mathrm{~F}$ & $\mathrm{~F}$ & $W$ & $\mathrm{Y}$ & $\mathrm{Y}$ \\
\hline Steve & 94 & $\mathrm{~F}$ & $\mathrm{M}$ & B & $Y$ & $\mathrm{Y}$ \\
\hline Maria & 89 & $\mathrm{M}$ & $\mathrm{F}$ & HI & $\mathrm{N}$ & $\mathrm{P}$ \\
\hline Terrell & 89 & $\mathrm{~F}$ & $\mathrm{M}$ & $\mathrm{B}$ & Y & Y \\
\hline Michelle & 89 & $\mathrm{M}$ & $\mathrm{F}$ & B & $\mathrm{P}$ & $\mathrm{Y}$ \\
\hline Natalie & 89 & $\mathrm{~F}$ & $\mathrm{~F}$ & $\mathrm{~B}$ & $\mathrm{Y}$ & $\mathrm{Y}$ \\
\hline Eduardo & 68 & $\mathrm{~F}$ & M & $\mathrm{HI}$ & $\mathrm{N}$ & $\mathrm{P}$ \\
\hline Ramone & 67 & $\mathrm{~F}$ & $\mathrm{M}$ & $\mathrm{HI}$ & $\mathrm{N}$ & $\mathrm{N}$ \\
\hline Duane & 65 & $\mathrm{~F}$ & $\mathrm{M}$ & B & $\mathrm{N}$ & $\mathrm{P}$ \\
\hline Demetrius & 65 & $\mathrm{~F}$ & $\mathrm{M}$ & B & $\mathrm{P}$ & $\mathrm{P}$ \\
\hline Sheree & 65 & $\mathrm{~F}$ & $\mathrm{~F}$ & B & $\mathrm{Y}$ & $\mathrm{Y}$ \\
\hline Takira & 63 & $\mathrm{~F}$ & $\mathrm{~F}$ & B & $Y$ & $Y$ \\
\hline Clifton & 63 & $\mathrm{~F}$ & $\mathrm{M}$ & B & $\mathrm{N}$ & $\mathrm{P}$ \\
\hline Richard & 63 & $\mathrm{~F}$ & $\mathrm{M}$ & $\mathrm{B}$ & $\mathrm{N}$ & $\mathrm{P}$ \\
\hline Andre & 63 & $\mathrm{~F}$ & $\mathrm{M}$ & B & $Y$ & $Y$ \\
\hline Teresa & 63 & $\mathrm{~F}$ & $\mathrm{~F}$ & B & $\mathrm{N}$ & $Y$ \\
\hline Jerome & 63 & $\mathrm{~F}$ & $\mathrm{M}$ & B & $Y$ & $Y$ \\
\hline Cleavon & 62 & $\mathrm{~F}$ & $\mathrm{M}$ & B & $\mathrm{Y}$ & $\mathrm{Y}$ \\
\hline
\end{tabular}

$\mathrm{B}=\mathrm{Black}$; W=White; $\mathrm{HI}=$ Hispanic $; \mathrm{Y}=\mathrm{Yes} ; \mathrm{N}=\mathrm{No} ; \mathrm{P}=$ Partial

Note: All names are pseudonyms 
Table 2. Observed Behaviors

\begin{tabular}{|c|c|c|c|c|c|c|c|}
\hline Name & $\begin{array}{c}\text { Physically } \\
\text { Close }\end{array}$ & $\begin{array}{c}\text { Read } \\
\text { Text }\end{array}$ & $\begin{array}{c}\text { Clear } \\
\text { Enunciation }\end{array}$ & $\begin{array}{c}\text { High } \\
\text { Expansions }\end{array}$ & In Tune & $\begin{array}{c}\text { Answer } \\
\text { Own } \\
\text { Questions }\end{array}$ & $\begin{array}{c}\text { Power } \\
\text { Dominance }\end{array}$ \\
\hline \multicolumn{8}{|c|}{ High Reynell Expressive Language Scorers at 36 mos. } \\
\hline Althea & No & Yes & Yes & No & Yes & Yes & Shared \\
\hline Bethany & No & No & Somewhat & Yes & Yes & Yes & Shared \\
\hline Antoine & No & No & No & Yes & Yes & Yes & Shared \\
\hline Chantelle & No & Yes & No & Somewhat & & Yes & Shared \\
\hline James & No & Somewhat & Yes & Yes & & Yes & Shared \\
\hline Lamont & Yes & Yes & Yes & No & & Yes & Shared \\
\hline Deborah & Yes & No & Yes & No & Yes & Yes & Shared \\
\hline Steve & Yes & Yes & Yes & Yes & Yes & Yes & Shared \\
\hline Maria & Yes & Yes & Somewhat & No & No & Yes & Shared \\
\hline Terrell & Yes & Yes & Somewhat & No & No & No & Shared \\
\hline Michelle & Yes & Yes & Somewhat & Yes & Yes & Yes & Shared \\
\hline Natalie & No & Yes & No & No & Yes & Yes & Shared \\
\hline \multicolumn{8}{|c|}{ Low Reynell Expressive Language Scorers at 36 mos. } \\
\hline Eduardo & No & Somewhat & & No & No & No & Child \\
\hline Ramone & No & No & es & Yes & Yes & Yes & Child \\
\hline Duane & Yes & No & No & No & Yes & No & Shared \\
\hline Demetrius & Somewhat & Somewhat & Somewhat & No & Yes & No & Shared \\
\hline Sheree & No & & No & No & No & Yes & Caregiver \\
\hline Takira & Yes & Yes & Somewhat & Somewhat & No & No & Child \\
\hline Clifton & & Yes & Somewhat & No & No & No & Caregiver \\
\hline Richard & & Yes & No & No & Somewhat & No & Caregiver \\
\hline Andre & & Yes & No & No & No & No & Caregiver \\
\hline Teresa & Somewhat & Somewhat & Somewhat & No & No & No & Caregiver \\
\hline Jerome & Yes & Yes & Yes & No & No & Yes & Caregiver \\
\hline Cleavon & No & Yes & Somewhat & No & No & No & None \\
\hline
\end{tabular}

Note: All names are pseudonyms 